\title{
Pengaruh Harga dan Kualitas Pelayanan terhadap Kepuasan Pelanggan Panderman Coffeee Shop di Masa Pandemi Covid-19
}

\author{
Stella Alvianna* \\ Program Diploma Kepariwisataan Universitas Merdeka Malang \\ Jalan Terusan Dieng No. 62-64 Kota Malang, Indonesia \\ stellaalvianna03@gmail.com
}

Ika Husnita

Program Diploma Kepariwisataan Universitas Merdeka Malang

Jalan Terusan Dieng No. 62-64 Kota Malang, Indonesia

ikahusniita@gmail.com

Syarif Hidayatullah

Fakultas Ekonomi dan Bisnis, Universitas Merdeka Malang

Jalan Terusan Dieng No. 62-64 Kota Malang, Indonesia

syarifok@yahoo.com

\author{
Alwin Lasarudin \\ Program Diploma Kepariwisataan Universitas Merdeka Malang \\ Jalan Terusan Dieng No. 62-64 Kota Malang, Indonesia \\ alwinlasarudin89@gmail.com \\ Estikowati \\ Program Diploma Kepariwisataan Universitas Merdeka Malang \\ Jalan Terusan Dieng No. 62-64 Kota Malang, Indonesia \\ estiwin97@gmail.com
}

Diterima: 09-02-2021

Disetujui: 16-06-2021

Dipublikasi: 30-06-2021

\begin{abstract}
ABSTRAK
Penelitian ini bertujuan untuk menganalisa Pengaruh Harga dan Kualitas Pelayanan Pramusaji Terhadap Kepuasan Pelanggan. Metode penelitian yang digunakan dalam penelitian ini adalah metode kuantitatif. Instrumen pengumpulan data yang digunakan adalah kuesioner. Variabel terikat dalam penelitian ini adalah variabel Kepuasan Pelanggan dan variabel bebas adalah Harga dan Kualitas Pelayanan di Panderman Coffee Shop Hotel Aria Gajayana Malang. Hasil penelitian ini adalah adanya pengaruh harga secara parsial yang positif dan signifikan terhadap kepuasan pelanggan yang sedang berkunjung di Panderman Coffee Shop Hotel Aria Gajayana Malang sesuai dengan keadaan dan perekonomian masyarakat pada masa pandemi covid-19. Secara parsial Kualitas Pelayanan berpengaruh positif dan signifikan terhadap Kepuasan Pelanggan yang berkunjung di Panderman Coffee Shop Hotel Aria Gajayana Malang pada masa pandemi covid-19. Kualitas Pelayanan yang diberikan oleh pihak Panderman Coffee Shop memberikan kesan sendiri bagi pelanggan untuk datang kembali ke Panderman Coffee Shop. Berdasarkan uji simultan (uji F) yang dilakukan untuk menguji ada tidaknya pengaruh variabel-variabel bebas (independen) secara simultan terhadap variabel terikat (dependen) sehingga dalam penelitian ini Harga dan Kualitas Pelayanan secara simultan berpengaruh positif terhadap Kepuasan Pelanggan pada masa pandemi covid-19. Berdasarkan hasil uji regresi yang menyatakan bahwa nilai koefisien regresi variabel Harga lebih besar dibandingkan nilai koefisien regresi Kualitas Pelayanan maka dapat disimpulkan bahwa pada masa pandemi covid-19 Harga berpengaruh dominan terhadap Kepuasan Pelanggan di Panderman Coffee Shop Hotel Aria Gajayana Malang.
\end{abstract}


Kata Kunci:

Harga; Kualitas Pelayanan; Kepuasan Pelanggan; Covid-19.

\section{ABSTRACT}

This study aims to analyze the effect of price and service quality of waiters on customer satisfaction. The research method used in this research is the quantitative method. The data collection instrument used was a questionnaire. The dependent variable in this study is the Customer Satisfaction variable and the independent variable is the Price and Service Quality at Panderman Coffeee Shop Hotel Aria Gajayana Malang. The result is that there is a partially positive and significant effect of price on customer satisfaction who is visiting the Panderman Coffee Shop Hotel Aria Gajayana Malang following the circumstances and the economy of the community during the Covid-19 pandemic. Partially Service Quality has a positive and significant effect on Customer Satisfaction who visits the Panderman Coffee Shop Hotel Aria Gajayana Malang during the Covid-19 pandemic. The quality of service provided by the Panderman Coffeee Shop gives its own impression for customers to come back to the Panderman Coffeee Shop. Based on the simultaneous test (F test) which was conducted to test whether the influence of independent (independent) variables simultaneously on the dependent variable (dependent) so that in this study Price and Service Quality simultaneously had a positive effect on Customer Satisfaction during the Covid-19 pandemic.. Based on the results of the regression test which states that the value of the Price variable regression coefficient is greater than the value of the Service Quality regression coefficient, it can be concluded that during the Covid-19 pandemic, Price has a dominant effect on Customer Satisfaction at Panderman Coffee Shop Hotel Aria Gajayana Malang.

Keywords:

Price; Service Quality; Customer Satisfaction; Covid-19. 


\section{PENDAHULUAN}

Industri kepariwisataan di Indonesia saat ini sudah berkembang cukup pesat. Meningkatnya jumlah wisatawan asing maupun domestik untuk melakukan perjalanan wisata menjadi peluang sekaligus tantangan bagi pengembangan pariwisata (Sowwam et al., 2018). Merebaknya covid-19 membuat semua sektor harus berbenah dan menyesuaikan diri atau dengan kata lain beradaptasi untuk tetap bertahan pada masa tersebut seperti penggunaan aplikasi dalam bidang pendidikan masa pandemi 19 (Fathirah et al., 2020) (Hidayatullah, Khouroh, et al., 2020) demikian halnya pada sektor perhotelan dan restoran di Jawa Timur merana. Banyak hotel yang memilih menutup operasional dan merumahkan karyawannya daripada menanggung biaya operasional. Kondisi ini berdampak juga terhadap goyahnya perekonomian daerah terkhusus pada daerah-daerah yang didominasi oleh sektor pariwisata, jasa serta industri seperti Kota Malang (Djausal et al., 2020) .

Berdasarkan informasi yang penulis dapat dari rekan kerja selama melakukan On The Job Training bahwa 4 bulan terakhir tingkat hunian Hotel Aria Gajayana Malang bervariasi dapat kita lihat penurunan jumlah tingkat hunian pada diagram batang sebagai berikut:

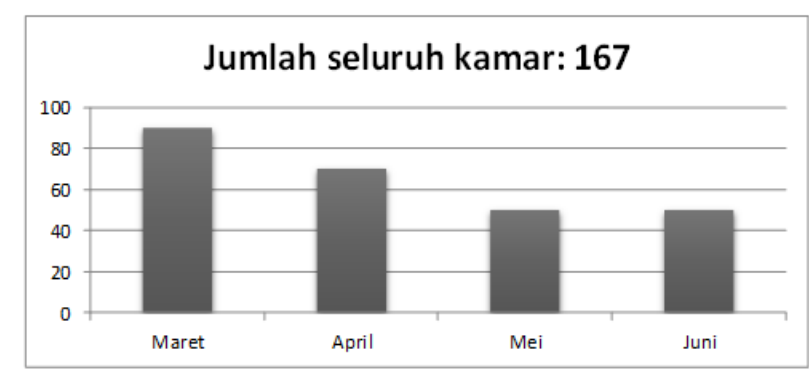

Gambar 1. Tingkat Hunian Hotel Aria Gajayana Malang

Sumber: Data Hotel Aria Gajayana Malang, diolah (2020)

Dari gambar 1 diketahui celah penelitian yang dapat dilakukan dimana tingkat kunjungan yang ada pada Hotel Aria Gajayana Malang dari bulan Maret-Juni dimana terjadi penurunan tingkat hunian. Total pemesanan kamar pada bulan Maret-Juni adalah 260 kamar yang terjual. Hal ini dikarenakan pandemi covid-19 yang mana berimbas sangat besar terhadap tingkat hunian yang ada di Hotel Aria Gajayana Malang. Penurunan tingkat hunian hotel juga berpengaruh pada Panderman Coffee Shop karena dari informasi awal yang diperoleh sebagian besar pengunjung Panderman Coffee Shop adalah penghuni Hotel Aria Gajayana Malang. Maka berdasarkan latar belakang yang telah dikemukakan diatas dalam penelitian ini penulis mengambil judul Pengaruh Harga dan Kualitas Pelayanan Pramusaji Terhadap Kepuasan Pelanggan di Panderman Coffee Shop Hotel Aria Gajayana Malang Pada Masa Pandemi Covid-19. Adapun perumusan masalah dalam penelitian ini adalah : 1) Apakah harga berpengaruh terhadap kepuasan pelanggan di Panderman Coffee Shop Hotel Aria Gajayana Malang pada masa pandemi Covid-19 ?, 2) Apakah kualitas pelayanan berpengaruh terhadap kepuasan pelanggan di Panderman Coffee Shop Hotel Aria Gajayana Malang pada masa pandemi Covid-19 ?, 3) Apakah harga dan kualitas pelayanan berpengaruh terhadap kepuasan pelanggan di Panderman Coffee Shop Hotel Aria Gajayana Malang pada masa pandemi covid-19 ?, 4) Manakah dari variabel harga dan 
kualitas pelayanan yang berpengaruh terhadap kepuasan pelanggan di Panderman Coffee Shop Hotel Aria Gajayana Malang pada masa covid-19?

\section{Pariwisata}

Menurut (Opportunity et al., 2011) pariwisata merupakan aktivitas perjalanan yang dilakukan untuk sementara waktu dari tempat asal ke daerah dengan tujuan bukan untuk menetap atau mencari nafkah melainkan hanya untuk memenuhi rasa ingin tahu menghabiskan waktu senggang atau libur serta tujuan-tujuan lainnya.

\section{Kualitas Pelayanan}

Menurut (Tjiptono \& Chandra, 2011) kualitas pelayanan adalah suatu keadaan dinamis yang berkaitan erat dengan produk jasa sumber daya manusia serta proses dan lingkungan yang dapat memenuhi atau dapat melebihi kualitas pelayanan yang diharapkan.

\section{Kepuasan}

Menurut (Inten Surya Utami \& Jatra, 2015) (Rakhmadian et al., 2017) kepuasan pelanggan adalah sikap keseluruhan yang diperlihatkan oleh pelanggan terhadap suatu produk setelah menggunakan atau mengkonsumsi produk.

\section{Covid-19}

Covid-19 merupakan nama penyakit yang disebabkan oleh virus corona. Nama tersebut diberikan oleh WHO (World Health Organization) sebagai nama resmi penyakit ini. Covid sendiri merupakan singkatan dari Corona Virus Disease-2019 yaitu penyakit yang disebabkan oleh virus corona yang menyerang saluran pernafasan sehingga menyebabkan demam tinggi, batuk, flu, sesak nafas serta nyeri tenggorokan (Velavan \& Meyer, 2020).

\section{Hipotesis}

1. Diduga harga berpengaruh terhadap kepuasan pelanggan di Panderman Coffee Shop Hotel Aria Gajayana Malang pada masa pandemi covid-19.

2. Diduga kualitas pelayanan berpengaruh terhadap kepuasan pelanggan di Panderman Coffee Shop Hotel Aria Gajayana Malang pada masa covid-19.

3. Diduga harga dan kualitas pelayanan berpengaruh terhadap kepuasan pelanggan di Panderman Coffee Shop Hotel Aria Gajayana Malang pada masa covid-19

4. Diduga kualitas pelayanan berpengaruh dominan terhadap kepuasan pelanggan di Panderman Coffee Shop Hotel Aria Gajayana Malang pada masa covid-19.

Berdasarkan uraian di atas, maka konsep kerangka konseptual dalam penelitian ini dapat dijelaskan pada gambar 2 berikut ini: 


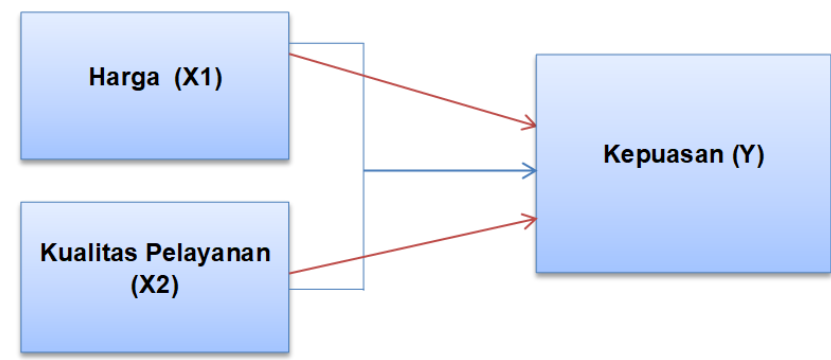

Gambar 2. Kerangka Konseptual Penelitian

\section{METODE RISET}

Ruang lingkup penelitian ini adalah harga dan kualitas pelayanan pramusaji yang digunakan untuk mengetahui tentang pengaruh harga dan kualitas pelayanan terhadap kepuasan pelanggan di Panderman Coffee Shop Hotel Aria Gajayana Malang pada masa covid-19. Populasi dalam penelitian ini adalah seluruh tamu yang pernah makan di Panderman Coffee Shop Hotel Aria Gajayana Malang pada bulan Maret-Juni 2020 berjumlah 260 orang. Dengan penarikan sampel metode slovin (Hidayat, 2017) dilakukan penentuan sampel dengan hasil sebesar 35 responden. Teknik pengambilan sampel menggunakan accidental random sampling, Sumber data dengan primer dan sekunder, teknik pengambilan data dengan menggunakan kuesioner secara online, mengingat masa pandemi, serta teknik analisis data dengan menggunakan analisis regresi linear berganda.

\section{Definisi Operasional}

Tabel 1. Definisi Operasional Variabel

\begin{tabular}{|c|c|c|c|}
\hline No. & Variabel penelitian & Definisi operasional & Indikator \\
\hline 1. & $\begin{array}{l}\text { Harga menurut Kotler } \\
\text { dan Amstrong (2013) }\end{array}$ & $\begin{array}{l}\text { Harga merupakan sejumlah uang } \\
\text { yang dibebankan atas suatu } \\
\text { barang atau jasa atau jumlah } \\
\text { uang yang ditukar oleh pelanggan } \\
\text { untuk manfaat-manfaat karena } \\
\text { memiliki atau menggunakan } \\
\text { produk jasa tersebut }\end{array}$ & $\begin{array}{l}\text { 1. Keterjangkauan harga } \\
\text { 2. Kesesuaian harga dengan } \\
\text { kualitas produk. } \\
\text { 3. Daya saing harga. } \\
\text { 4. Kesesuaian harga dengan } \\
\text { manfaat }\end{array}$ \\
\hline 2. & $\begin{array}{lr}\text { Kualitas } & \text { Pelayanan } \\
\text { menurut } & \text { Goetsch dan } \\
\text { Davis } & \text { dalam } \\
\text { Hardiansyah (2011) }\end{array}$ & $\begin{array}{l}\text { Kualitas pelayanan merupakan } \\
\text { sesuatu yang berhubungan } \\
\text { dengan terpenuhinya harapan } \\
\text { atau kebutuhan pelanggan } \\
\text { dimana pelayanan dapat } \\
\text { dikatakan berkualitas jika dapat } \\
\text { menyediakan produk dan } \\
\text { pelayanan sesuai dengan } \\
\text { kebutuhan dan harapan } \\
\text { pelanggan. }\end{array}$ & $\begin{array}{l}\text { a.Tangible (berwujud) } \\
\text { b.Reliability (kehandalan) } \\
\text { c.Responsiviness (ketanggapan) } \\
\text { d.Assurance (Jaminan) } \\
\text { e.Emphaty (empati) }\end{array}$ \\
\hline 3. & $\begin{array}{l}\text { Kepuasan pelanggan } \\
\text { menurut Windasuri dan } \\
\text { Hyacinta (2017) }\end{array}$ & $\begin{array}{l}\text { Kepuasan pelanggan adalah } \\
\text { tanggapan emosional dari hasil } \\
\text { tanggapan konsumen atas } \\
\text { konsumsi produk atau pelayanan }\end{array}$ & $\begin{array}{l}\text { a.Ketersediaan } \\
\text { merekomendasikan } \\
\text { b.Minat berkunjung kembali } \\
\text { c.Kesesuaian harapan }\end{array}$ \\
\hline
\end{tabular}

Sumber : Berbagai Artikel - diolah - 2020 


\section{HASIL PENELITIAN DAN PEMBAHASAN}

Dari hasil SPSS yang dilakukan diperoleh hasil sebagai berikut :

Tabel 2. Hasil Perhitungan SPSS

\begin{tabular}{|c|c|c|c|c|}
\hline Keterangan & Koefisien Regresi & t Hitung & Sig. & Keterangan \\
\hline Harga & 0.592 & 12.840 & 0.000 & Signifikan \\
\hline Kualitas Pelayanan & 0.160 & 3.171 & 0.002 & Signifikan \\
\hline Konstanta & & -715 & & \\
\hline $\mathrm{R}$ & & 0.883 & & \\
\hline Adjusted R Square & & 0.772 & & \\
\hline F hitung & & 100.733 & & \\
\hline Sig F & & 0.000 & & \\
\hline $\mathrm{N}$ & & 60 & & \\
\hline Variabel terikat & Kepuasan Pelanggan & & & \\
\hline F tabel & 3.16 & & & \\
\hline $\mathrm{t}$ tabel & 2.000172 & & & \\
\hline
\end{tabular}

Diketahui constant sebesar -0,715 sedang nilai harga (b/koefisien regresi) sebesar 0,592 dan nilai kepuasan (b/koefisien regresi) sebesar 0,160 sehingga persamaan regresinya diketahui:

$$
\begin{aligned}
& Y=a+b 1 X 1+b 2 X 2+e \\
& Y=-0,715+0,592 X 1+0,160 X 2
\end{aligned}
$$

\section{Uji Hipotesis}

Berdasarkan hasil uji regresi berganda diketahui variabel harga dan kualitas pelayanan secara bersama-sama atau simultan berpengaruh terhadap kepuasan pelanggan di Panderman Coffee Shop Hotel Aria Gajayana Malang. Untuk melihat pengaruh secara simultan ini dapat dilihat dari hasil uji F. Nilai F hitung sebesar 100.733. Maka dapat disimpulkan bahwa F hitung > F tabel $(100.733>4.010)$ yang berarti bahwa harga dan kualitas pelayanan secara bersama-sama atau simultan berpengaruh terhadap kepuasan pelanggan di Panderman Coffee Shop Hotel Aria Gajayana Malang pada masa covid19.

\section{Pengaruh Harga Terhadap Kepuasan Pelanggan di Panderman Coffee Shop Hotel Aria Gajayana Malang Pada Masa Pandemi Covid-19}

Hasil penelitian ini menunjukkan adanya pengaruh harga secara parsial yang positif dan signifikan terhadap kepuasan pelanggan yang sedang berkunjung di Panderman Coffee Shop Hotel Aria Gajayana Malang sesuai dengan keadaan dan perekonomian masyarakat pada masa Covid-19. Harga digunakan sebagai indikator kualitas produk yang menjadi tolak ukur sebagai kualitas yang lebih baik dari suatu produk yang menentukan kepuasan lebih tinggi. Oleh karena itu harga yang ditetapkan harus sebanding dengan kualitas yang diberikan kepada pelanggan. Berdasarkan hasil pengujian hipotesis 1 tentang pengaruh harga terhadap kualitas pelayanan diperoleh keterangan bahwa variabel harga memiliki pengaruh yang signifikan terhadap kepuasan pelanggan yaitu sebesar 0.00 lebih kecil dari 0.05. dimana pada hasil uji t diketahui bahwa nilai t hitung sebesar 12.840 yang berarti semakin baik harga yang ditawarkan maka akan semakin baik kepuasan pelanggan. Hasil penelitian ini mendukung hasil penelitian sebelumnya yang dilakukan oleh (Nasution, 2017) dalam penelitiannya yang berjudul 
Alvianna, S., et al., (2021). Pengaruh Harga dan Kualitas Pelayanan terhadap ....

The Effect of Price and Service Quality on Customer Satisfaction and Loyalty Customer Waroeng Steak and Shake Medan dimana dalam hasil penelitiannya adalah harga berpengaruh terhadap loyalitas pelanggan. Penelitian ini juga sejalan dengan penelitian yang dilakukan oleh (Alvianna \& Hidayatullah, 2020)(Cristo et al., 2017)(Alvianna, 2017)(Shartykarini et al., 2016).

Pengaruh Kualitas Pelayanan Terhadap Kepuasan Pelanggan Di Panderman Coffee Shop Hotel Aria Gajayana Malang Pada Masa Pandemi Covid-19.

Hasil penelitian ini menunjukkan adanya pengaruh kualitas pelayanan secara parsial yang positif dan signifikan terhadap kepuasan pelanggan yang berkunjung di Panderman Coffee Shop Hotel Aria Gajayana Malang pada masa covid-19. Kualitas pelayanan yang diberikan oleh pramusaji Panderman Coffee Shop memberikan kesan yang baik bagi pelanggan untuk berkunjung kembali ke Panderman Coffee Shop. Suatu perusahaan yang mengutamakan kualitas pelayanan yang baik dapat memberikan dampak positif terhadap kepuasan pelanggan. Berdasarkan hasil pengujian hipotesis 2 pada penelitian ini terdapat pengaruh yang signifikan sebesar 0.02 lebih kecil dari 0.05 antara kualitas pelayanan terhadap kepuasan pelanggan dan pada hasil uji t diketahui bahwa nilai t hitung sebesar 3.171. Hal ini menunjukkan bahwa kualitas pelayanan merupakan faktor yang perlu diperhatikan untuk meningkatkan kepuasan pelanggan pada bidang kuliner. Kualitas pelayanan dapat dilihat pada persepsi masyarakat (pelanggan) yang menerima layanan. Karena pelanggan yang merasakan pelayanan yang diberikan maka pelangganlah yang dapat menilai dan menentukan kualitas pelayanan. Apabila pelayanan yang diberikan atau dirasakan sesuai dengan yang diharapkan maka kualitas pelayanan yang dipersepsikan baik dan memuaskan. Sebaliknya apabila pelayanan yang diberikan rendah dari yang diharapkan maka kualitas pelayanan dipersepsikan buruk. Dengan demikian baik atau buruknya kualitas pelayanan bergantung pada kemampuan penyedia layanan untuk memenuhi harapan pelanggan.

Hasil penelitian ini mendukung hasil penelitian sebelumnya yang dilakukan oleh (Cristo et al., 2017) dalam penelitiannya yang berjudul The Influence Of Price Service Quality And Physical Environment On Customer Satisfaction Case Study markobar cafe manado dimana dalam hasil penelitiannya kualitas pelayanan berpengaruh signifikan terhadap kepuasan pelanggan yang berarti meningkat atau menurunnya kepuasan pelanggan dapat dipengaruhi oleh kualitas pelayanan. Penelitian ini juga mendukung penelitian yang dilakukan oleh (Hidayatullah, Rachmawati, et al., 2020) Dimana hasilnya kualitas pelayanan berpengaruh terhadap Kepuasan Terhadap Loyalitas Generasi Milenial Berkunjung ke Tempat Wisata.

\section{Pengaruh Harga Dan Kualitas Pelayanan Terhadap Kepuasan Pelanggan di Panderman Coffee Shop Hotel Aria Gajayana Malang Pada Masa Pandemi Covid-19.}

Uji simultan (Uji F) dilakukan untuk menguji ada tidaknya pengaruh variabel-variabel bebas (independen) secara simultan terhadap variabel terikat (dependen). Hasil analisis uji $\mathrm{F}$ dengan menggunakan program SPSS release 16.0 diperoleh $\mathrm{F}$ hitung $=100.733$ dengan nilai signifikan 0.000 karena nilai signifikan <0.05 maka Ho ditolak hal ini menunjukkan bahwa H3 yang menyatakan diduga 
harga dan kualitas pelayanan berpengaruh terhadap kepuasan pelanggan di Panderman Coffee Shop Hotel Aria Gajayana Malang pada masa pandemi covid-19 diterima. Untuk mengetahui besarnya kontribusi pengaruh harga dan kualitas pelayanan secara simultan terhadap kepuasan pelanggan Panderman Coffee Shop Hotel Aria Gajayana Malang pada masa pandemi covid-19 dapat diketahui berdasarkan nilai Adjusted $R$ Square. Dari output SPSS diperoleh nilai Adjusted $R$ Square sebesar 0.772. nilai tersebut menunjukkan bahwa kedua variabel bebas yaitu harga dan kualitas pelayanan mampu menjelaskan variasi variabel terikat yaitu kepuasan pelanggan sebesar $77.2 \%$ hal ini berarti $22.8 \%$ variasi variabel kepuasan pelanggan dapat dijelaskan oleh faktor lain di luar model regresi dalam penelitian ini.

Hasil penelitian ini mendukung hasil penelitian sebelumnya yang dilakukan oleh (Runtunuwu et al., 2014) dalam penelitiannya yang berjudul Pengaruh Kualitas Produk, Harga, Dan Kualitas Pelayanan Terhadap Kepuasan Pengguna Cafe Dan Resto Cabana Manado. Hasilnya variabel kualitas produk, variabel harga dan variabel kualitas pelayanan memiliki berpengaruh yang positif pada kepuasan pengunjung di Cafe dan Resto Cabana di Manado. Penelitian ini juga mendukung atau sejalan dengan penelitian yang dilakukan oleh (Sandrio et al., 2020) dan (Alvianna \& Hidayatullah, 2020) (Gulla et al., 2015)(Sejati, 2016).

\section{Variabel Yang Paling Dominan Berpengaruh Terhadap Kepuasan Pelanggan di Panderman Coffee Shop Hotel Aria Gajayana Malang Pada Masa Pandemi Covid-19.}

Pada hipotesis 4 diduga Kualitas Pelayanan (X2) merupakan variabel yang paling dominan berpengaruh terhadap Kepuasan Pelanggan (Y) namun berdasarkan hasil uji regresi dengan melihat nilai koefisien regresi bahwa nilai koefisien regresi variabel Harga (X1) sebesar 0.592 dan nilai koefisien regresi variabel Kualitas Pelayanan sebesar 0.160 maka dapat disimpulkan bahwa pada penelitian ini variabel Harga (X1) dan Kualitas Pelayanan (X2) yang berpengaruh dominan terhadap Kepuasan Pelanggan adalah Variabel Harga artinya yang menjadi tolak ukur Kepuasan Pelanggan di Panderman Coffee Shop Hotel Aria Gajayana Malang pada masa Covid-19 adalah harga menu makanan yang ditawarkan pada masa covid-19 di Panderman Coffee Shop adalah sesuai dengan kebutuhan dan keinginan pelanggan.

Hasil penelitian ini mendukung hasil penelitian sebelumnya yang dilakukan oleh Chyntia Violita Wijaya (2017) dalam penelitiannya yang berjudul Pengaruh Harga Kualitas Pelayanan dan Kualitas Produk Terhadap Kepuasan Konsumen Depot Madiun Masakan Khas Bu Rudy dimana dalam hasil penelitiannya adalah Harga memberi pengaruh dominan terhadap Kepuasan Pelanggan. Demikian halnya penelitian ini mendukung penelitian yang dilakukan oleh (Pratama et al., 2021) (Wibowo et al., 2021) tentang kepuasan pelanggan 


\section{KESIMPULAN DAN SARAN}

Berdasarkan uji simultan (uji F) yang dilakukan untuk menguji ada tidaknya pengaruh variabelvariabel bebas (independen) secara simultan terhadap variabel terikat (dependen) sehingga dalam penelitian ini Harga dan Kualitas Pelayanan secara simultan berpengaruh positif terhadap Kepuasan Pelanggan pada masa pandemi covid-19. Berdasarkan hasil uji regresi yang menyatakan bahwa nilai koefisien regresi variabel Harga lebih besar dibandingkan nilaI koefisien regresi Kualitas Pelayanan maka dapat disimpulkan bahwa pada masa pandemi Covid-19 Harga berpengaruh dominan terhadap Kepuasan Pelanggan di Panderman Coffee Shop Hotel Aria Gajayana Malang. Penelitian ini hanya melihat kepuasan dari sisi harga dan kualitas pelayanan, peneliti lain dapat juga menghubungi kepuasan dengan menggunakan atau menambahkan variabel lain seperti sistem informasi (Alvianna, Earlike, et al., 2020), media sosial (Amelia, Rizka; Hidayatullah, 2020) (Rachmawati et al., n.d.), transportasi menuju lokasi (Syarif Hidayatullah, Setiyorini, Irany Windhyastiti, 2020), kemudahan penggunaan website (Hidayatullah, 2020) (Rachmawati, 2020), (Rachmawati et al., n.d.). Disamping itu perlu diperhatikan pengembangan usaha di masa pandemic ini dengan cara melakukan inovasi dan kreasi dengan memperhatikan standar kesehatan, inovasi dan kreasi dapat dikategorikan sebagai entrepreneurial marketing yang pada akhirnya dapat menjadikan usaha atau perusahaan kita dengan perusahaan lain (Hidayatullah et al., 2019), (Khouroh et al., 2020)(Hidayatullah, Rachmawati, et al., 2020). Yang tidak kalah pentingnya perlu memperhatikan juga usia pengunjung yang saat ini didominasi usia millennial, sehingga karakteristik dan pola hidup usia generasi milenial juga perlu diperhatikan (Alvianna, Patalo, et al., 2020) (Hidayatullah et al., 2018) (Hidayatullah, Rachmawati, et al., 2020). Dalam pengembangan usaha seperti penambahan fasilitas maupun luas Coffee perlu juga diperhatikan sistem investasi yang ada sehingga dana investasi pengembangan Coffee dapat digunakan secara maksimal(Windhyastiti et al., 2019) (Cramez et al., 2021) (Windhyastiti et al., 2021). 


\section{DAFTAR PUSTAKA}

Alvianna, S. (2017). Analisis Pengaruh Harga, Produk, Dan Kualitas Layanan Terhadap Kepuasan Wisatawan Di Taman Wisata Air Wendit Kabupaten Malang. Jurnal Pariwisata Pesona. https://doi.org/10.26905/jpp.v2i1.1263

Alvianna, S., Earlike, F., Sani, A., Lasarudin, A., dan Hidayatullah, S. (2020). The Impact of Visitor Satisfaction Mediation from the Relationship between Marketing Information Systems, Tourist Destinations and Service Quality towards Returning Interest in Malang Topeng Village Tourism Destinations. 4413(12), 332-338. https://doi.org/10.36349/easjmb.2020.v03i12.003

Alvianna, S. dan Hidayatullah, S. (2020). Pengaruh kualitas harga layanan dan kepuasan terhadap kesetiaan usia milenial berkunjung ke tempat wisata 1,2. 18. https://doi.org/10.36275/mws

Alvianna, S., Patalo, R. G., Hidayatullah, S. dan Rachmawati, I. K. (2020). Pengaruh Attraction, Accessibility, Amenity, Ancillary Terhadap Kepuasan Generasi Millenial Berkunjung ke Tempat Wisata. 4, 53-59. https://doi.org/10.34013/jk.v4i2.41

Amelia, R. dan Hidayatullah, S. (2020). The Effect of Instagram Engagement to Purchase Intention and Consumers 'Luxury Value Perception as the mediator in the Skylounge Restaurant. 5(4), 958966.

Cramez, A. M. J. N., Hidayatullah, S., Alvianna, S., Setioko, M. D., dan Krisnanda, R. (2021). Perspective Of Tourism Development In Bijagos Island ( Guinea-Bissau ) As Well As Community Economic Growth. 9(1), 3766-3773.

Cristo, M., Saerang, D., dan Worang, F. (2017). The Influence Of Price, Service Quality, And Physical Environment On Customer Satisfaction. Case Study Markobar Cafe Mando. Jurnal Riset Ekonomi, Manajemen, Bisnis Dan Akuntansi. https://doi.org/10.35794/emba.v5i2.15962

Djausal, G. P., Larasati, A., dan Muflihah, L. (2020). Strategi Pariwisata Ekologis Dalam Tantangan Masa Pandemik Covid-19. Jurnal Perspektif Bisnis. https://doi.org/10.23960/jpb.v3i1.15

Fathirah, Puteri, S. L. E., dan Arnesia, P. D. (2020). Analisis Google Classroom Sebagai Sistem Pembelajaran Jarak Jauh Saat Pandemi Covid-19 Menggunakan Model Kesuksesan Sistem Informasi DeLone Dan McLean. Seminar Nasional Teknologi Informasi Dan Komunikasi STI\&K (SeNTIK). 
Gulla, R., Oroh, S. G., dan Roring, F. (2015). Analisis Harga, Promosi, Dan Kualitas Pelayanan Terhadap Kepuasan Konsumen Pada Hotel Manado Grace Inn. Jurnal Riset Ekonomi, Manajemen, Bisnis Dan Akuntansi.

Hidayat, A. (2017). Cara Hitung Rumus Slovin Besar Sampel. Statistikian.

Hidayatullah, S. (2020). Website Quality: The Effect with Perceived Flow and Purchase Intention in Travel Customers in Malang City. 5(11).

Hidayatullah, S., Firdiansjah, A., Patalo, R. G., dan Waris, A. (2019). The effect of entrepreneurial marketing and competitive advantage on marketing performance. International Journal of Scientific and Technology Research.

Hidayatullah, S., Khouroh, U., Windhyastiti, I., Patalo, R. G., dan Waris, A. (2020). Implementasi Model Kesuksesan Sistem Informasi DeLone And McLean Terhadap Sistem Pembelajaran Berbasis Aplikasi Zoom Di Saat Pandemi Covid-19. Jurnal Teknologi Dan Manajemen Informatika. https://doi.org/10.26905/jtmi.v6i1.4165

Hidayatullah, S., Rachmawati, I. K., Aristanto, E., Waris, A., dan Patalo, R. G. (2020). Peran Sistem Informasi Pemasaran, Kualitas Pelayanan dan Entrepreneurial marketing serta Kepuasan Terhadap Loyalitas Generasi Milenial Berkunjung ke Tempat Wisata. https://doi.org/10.32812/jibeka.v14i1.148

Hidayatullah, S., Waris, A., dan Devianti, R. C. (2018). Perilaku Generasi Milenial dalam Menggunakan Aplikasi Go-Food. Jurnal Manajemen Dan Kewirausahaan. https://doi.org/10.26905/jmdk.v6i2.2560

Inten Surya Utami, I., dan Jatra, I. (2015). Pengaruh Kualitas Layanan Terhadap Kepuasan Pelanggan Restoran Baruna Sanur. E-Jurnal Manajemen Universitas Udayana.

Khouroh, U., Sudiro, A., Rahayu, M., dan Indrawati, N. K. (2020). The mediating effect of entrepreneurial marketing in the relationship between environmental turbulence and dynamic capability with sustainable competitive advantage: An empirical study in Indonesian MSMEs. Management Science Letters. https://doi.org/10.5267/j.msl.2019.9.007

Nasution, S. M. A. (2017). The Effect of Price and Service Quality on Customer Satisfaction and Loyalty Customer Waroeng Steak and Shake Medan. Proceedings of The 7th Annual International Conference (AIC) Syiah Kuala University and The 6th International Conference on 
Multidisciplinary Research (ICMR) in Conjunction with the International Conference on Electrical Engineering and Informatics (ICELT.

Opportunity, T., Sosa, I., Keenan, K., Influencing, F., In, P., Hunting, R., Technical, T., Hilson, G., Dunk, T., Legg, D., Samson, C., Pretty, J., O’Keefe, J. H., Vogel, R., Lavie, C. J., Cordain, L., Keyes, C. L. M., Derksen, L., Lightfoot, N. E., ... San Joaquin Valley Air Pollution Control District. (2011). A Guide to the Management for Tailings Facilities. Food Policy.

Pratama, B. P., Hidayatullah, S., dan Alvianna, S. (2021). Mediation Effect of Customer Satisfaction from the Relationship between System Quality, Information Quality, and Service Quality towards Interests of Tourist Visiting in East Java Park 3. 6(1), 95-100.

Rachmawati, I. K. (2020). Collaboration Technology Acceptance Model , Subjective Norms and Personal Innovations on Buying Interest Online. International Journal of Innovative Science and Research Technology, 5(11).

Rachmawati, I. K., Hidayatullah, S., Nuryanti, F., dan Wulan, M. (n.d.). The Effect Of Consumer Confidence On The Relationship Between Ease Of Use And Quality Of Information On Online Purchasing Decisions.

Rakhmadian, M., Hidayatullah, S., Respati, H., dan Malang, U. M. (2017). Analisis Kualitas Sistem Dan Kualitas Informasi Terhadap Kepuasan Pemakai Sistem Informasi Akademik Dosen. Seminar Nasional Sistem Informasi, September, 665-675.

Runtunuwu, J., Oroh, S., dan Taroreh, R. (2014). Pengaruh Kualitas Produk, Harga, Dan Kualitas Pelayanan Terhadap Kepuasan Pengguna Cafe Dan Resto Cabana Manado. Jurnal Riset Ekonomi, Manajemen, Bisnis Dan Akuntansi. https://doi.org/10.35794/emba.v2i3.5973

Sandrio, L., Hidayatullah, S., Supriadi, B., dan Patalo, R. G. (2020). Effect Of Tourism Satisfaction As A Mediator Variable Of Images Of Destination And Facilities To Loyalties On Millennial Generation To Visit Bromo Tengger Semeru. 9(05), 183-187.

Sejati, B. S. A. (2016). Pengaruh Kualitas Produk, Kualitas Pelayanan, Dan Harga Terhadap Keputusan Pembelian Pada Starbucks. Jurnal Ilmu Dan Riset Manajemen ISSN : 2461-0593.

Shartykarini, S., Firdaus, R., dan Rusniati. (2016). Pengaruh Harga, Kualitas Produk Dan Kualitas Layanan Terhadap Kepuasan Pelanggan Dalam Membentuk Loyalitas Pelanggan (Studi Pengunjung Cafe di Banjarbaru). Jurnal Wawasan Manajemen. 
Sowwam, M., Riyanto, Anindita, D., Riyadi, S. A., dan Qibthiyyah, R. M. (2018). Kajian Dampak Sektor Pariwisata Terhadap Perekonomian Indonesia. Kementerian Pariwisata Republik Indonesia.

Syarif Hidayatullah, Setiyorini, Irany Windhyastiti, I. K. R. (2020). Peran Aksesibilitas, Konektivitas, Kualitas Layanan Terhadap Loyalitas Pengguna Angkutan Umum Melalui Kepuasan Penumpang Sebagai Variabel Mediator. Seminar Nasional Sistem Informasi (SENASIF-4), 2261-2274.

Tjiptono, F., dan Chandra, G. (2011). Service, Quality \& Satisfaction. In Edisi 4. https://doi.org/10.3389/fgene.2015.00293

Velavan, T. P., dan Meyer, C. G. (2020). The COVID-19 epidemic. In Tropical Medicine and International Health. https://doi.org/10.1111/tmi.13383

Wibowo, R., Alvianna, S., Hidayatullah, S., Astuti, W., dan Setioko, M. D. (2021). Analysis of the Influence of Tourist Destinations and Service Quality on Tourist Satisfaction Visiting the Jawa Timur Park in the New Normal Era. 6(1).

Windhyastiti, I., Hidayatullah, S., dan Khouroh, U. (2021). Investment attractiveness rating and factors affecting. Accounting. https://doi.org/10.5267/j.ac.2020.10.001

Windhyastiti, I., Hidayatullah, S., Khouroh, U., dan Waris, A. (2019). Role of The Online Single Submission (OSS) To Increase The City Investment Attraction. 4th International Conference Of Graduate School On Sustainability (ICGSS) 2019, 1-6. 